\title{
㭪後性上影言胞の臨床的研究
}

\author{
宫沢正純・白石典彦・石原博人
}

曾田忠雄・伊藤唀夫

\section{Clinical study of postoperative maxillary cyst}

\author{
Masazumi Mryazawa - Toyohiko Shiraishi - Hirohito Ismihara \\ Tadao SodA - Hideo IтOH
}

腥

-

副算㹣炎の手術後数年から10数年を绎てから発見され

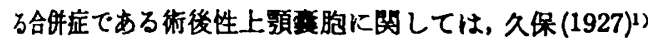

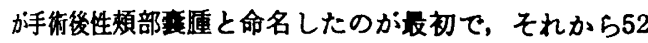
年を侱過し，この間に報告された多数の蹦床的ならびに 基荻的研究によって，本萁胞の病態はしだいに明らかに なってきた。

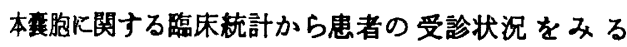
と, 一般に眼球突出, 眼球偏位などの眼症状を有する場 合には眼科を訪れ，上頻部の腫脹または疼痛，あるいは

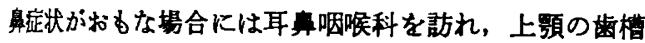
部の隀脹ないしは日歯部の異和感などがおすな場合には 歯科または口腔外科を訪れることが多いようである。乙 たがって以上の 3 科から報告されている茟胞の存在部 位、ならびにそれに伴ら諸症状の発現頻度には多少の连 いがある゙，われわれは過去 5 年 9 か月間に怪悇 した

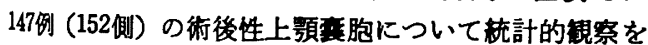
行ったので，その結果の概要を報告する。

\section{研 究 対 象}

1972年 1 月から1977年 9 月までの 5 年 9 か月間に東京

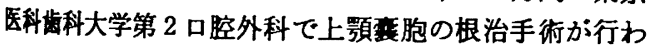
れた症例のらち, 既往歴, 術前検査および手術所見から

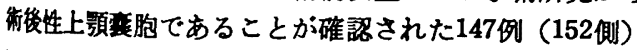
について調查を行った。

東京医科科大学齿学部第 2 口膑外科学教室 （主任：色萌秀夫教授）

The Second Department of Oral Surgery, Faculty of Dentistry, Tokyo Medical and Dental University (Chief: Prof. Hideo Itoh)

受付日：昭和54年 7 月 26 日

\section{研究 结 帛}

\section{1. 性別}

患者の性別は男性94例，女性 53例で男女比は 1.8:1 であり（表 1),これは副算腔炎の手衍を受ける患者は

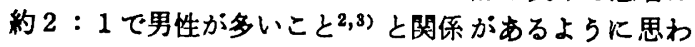
れた。

\section{2. 㭧側別}

英胞の左右侧別恃表 2 のようで，片側性 142 例，両側 性 5 例で, 片側性の左右别は右例 76 例，左側 66 例であ り，従来の統計と同しく，左右には有意差はなかった。

\section{3. 年些}

患者の年龄は表 1 のようで，30綗代が最高の約40\%，

表 1 患者の年踰および性別

\begin{tabular}{c|r|r|r}
\hline 年 & 男 & 女 & 計 $(\%)$ \\
\hline $20 \sim 24$ & 2 & 1 & $3(2.0)$ \\
$25 \sim 29$ & 7 & 10 & $17(11.6)$ \\
$30 \sim 34$ & 23 & 8 & $31(21.1)$ \\
$35 \sim 39$ & 16 & 11 & $27(18.4)$ \\
$40 \sim 44$ & 13 & 6 & $19(12.9)$ \\
$45 \sim 49$ & 12 & 10 & $22(15.0)$ \\
$50 \sim 54$ & 6 & 1 & $7(4.8)$ \\
$55 \sim 59$ & 5 & 3 & $8(5.4)$ \\
$60 \sim$ & 10 & 3 & $13(8.8)$ \\
\hline 計 & 94 & 53 & $147(100)$ \\
\hline
\end{tabular}

表 2 患㑡別

\begin{tabular}{c|r|r|r}
\hline & 男 & 女 & 計 \\
\hline 右 㑡 & 48 & 28 & 76 \\
左 㑡 & 43 & 23 & 66 \\
両 㑡 & 3 & 2 & 5 \\
\hline 計 & 94 & 53 & 147 \\
\hline
\end{tabular}




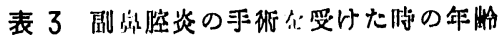

\begin{tabular}{|c|c|c|c|}
\hline 年 椧 & 男 & 女 & 斯 $(\%)$ \\
\hline $10 \sim 14$ & 13 & 9 & $22(15.0)$ \\
\hline $15 \sim 19$ & 44 & 26 & $70(47.6)$ \\
\hline $20 \sim 24$ & 16 & 9 & $25(17.0)$ \\
\hline $25 \sim 29$ & 13 & 4 & $17(11.6)$ \\
\hline $30 \sim 34$ & 2 & 1 & $3(2.0)$ \\
\hline $35 \sim 39$ & 1 & 3 & $4(2.7)$ \\
\hline $40 \sim 44$ & 3 & 1 & $4(2.7)$ \\
\hline $45 \sim 49$ & 1 & 0 & $1(0.7)$ \\
\hline $50 \sim 54$ & 1 & 0 & $1(0.7)$ \\
\hline 計 & 94 & 53 & $147(100)$ \\
\hline
\end{tabular}

表 4 垔胞が発見されるまでの跀間

\begin{tabular}{c|r|r|r}
\hline 期間（年） & 男 & 女 & 計 (\%) \\
\hline $1 \sim 5$ & 0 & 0 & $0(0)$ \\
$6 \sim 9$ & 5 & 5 & $10(6.8)$ \\
$10 \sim 19$ & 44 & 25 & $69(46.9)$ \\
$20 \sim 29$ & 23 & 14 & $37(25.2)$ \\
$30 \sim 39$ & 11 & 6 & $17(11.6)$ \\
$40 \sim 49$ & 10 & 3 & $13(8.8)$ \\
$50 \sim$ & 1 & 0 & $1(0.6)$ \\
\hline 計 & 94 & 53 & $147(100)$ \\
\hline
\end{tabular}

次が40歳代の約 $28 \%$ で，全症例の約 $93 \%$ は30歳以上の 中高年龄者であった。

\section{4. 副鼻腔炎の手術を受けた時の年齢}

最初に副鼻腔炎の手術を受けた時の年柃は表 3 のよう で, 15歳から19歳までが最も多く約 $47.6 \%$, 次が20～24歳 および10１4歳のそれぞれ約 $17 \%$ と 15\% で，全症例の 79.6\%は10〜25歳の比較的若い年代であった.

\section{5. 本害胞が発見されるまでの期間}

本孪胞の症状は最初の副鼻腔炎手術から数年ないしは 10数年を経てから出現することが多いといわれている. 今回のわれわれの調查結果も同様で（表 4)，鼻症状， 頓部の腫脹または疼痛, 歯の異和感などの症状が出現す るまでの期間はかなり長く，約 $47 \%$ は 10１9年後に，約 $25 \%$ は20 29年後に何らかの症状が自覚されて拈り，40 年以上のものも $9.4 \%$ あった。 それに対して 5 年以下の ものはなく, $6 〜 9$ 年後はわずか $6.8 \%$ であった.

副奥腔炎手術後の 経過年数之患者年齢との関係を 飯 沼4)らの方法により分析した結果は図1のようで，手術 年齢が若いと撨胞の症状が出現するまでの期間が短い傾 向がみられ，手術年龃が 20 歳代の場合には $6 \sim 15$ 年の間 に，30歳代の場合には11〜20年の間に，40歳代の場合に

\begin{tabular}{|c|c|c|c|c|c|c|c|}
\hline $41 \sim$ & & & & & & 3 & 3 \\
\hline $31 \sim 40$ & & & & & 6 & 5 & 5 \\
\hline $21-30$ & & & & 5 & 18 & 3 & 1 \\
\hline $16-20$ & & & & 27 & 12 & 1 & 4 \\
\hline $11 \sim 15$ & & & 8 & 22 & 4 & 2 & \\
\hline $6-10$ & & & 12 & 4 & 1 & 1 & \\
\hline \multirow[t]{2}{*}{-5} & & & & & & & \\
\hline & $\int_{14}^{10}$ & $\begin{array}{c}15 \\
19 \\
19\end{array}$ & $\int_{29}^{20}$ & $\underset{39}{30}$ & $\int_{49}^{40}$ & ${ }_{59}^{50}$ & 60 \\
\hline
\end{tabular}

谣胞発見時の年粉

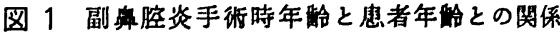

表 5 自覚症状

\begin{tabular}{|c|c|c|c|}
\hline 部 位 & 症 状 & 例数 & 計 \\
\hline 頓部症状 & $\begin{array}{c}\text { 腫 脹 } \\
\text { 腫脹・疼痛 } \\
\text { 疼 痛 } \\
\text { 腫脹・麻㾝感 }\end{array}$ & $\begin{array}{r}10 \\
4 \\
4 \\
2\end{array}$ & 20 \\
\hline 煩部 - 口腔症状 & $\begin{array}{c}\text { 腫 } \\
\text { 脹 } \\
\text { 㾝脹・疼痛 } \\
\text { 疼 } \\
\text { 痛 } \\
\text { 異 麻㾴感 } \\
\text { 感 } \\
\text { 㾝 感 }\end{array}$ & $\begin{array}{r}38 \\
37 \\
10 \\
8 \\
15 \\
2\end{array}$ & 110 \\
\hline 口腔症状 & $\begin{array}{c}\text { 尰脹・疼痛 } \\
\text { 異 和 感 } \\
\text { 疼 痛 } \\
\text { 疼痛・瘦孔 }\end{array}$ & $\begin{array}{r}12 \\
5 \\
3 \\
2\end{array}$ & 22 \\
\hline 眼 症 状 & & 0 & 0 \\
\hline 鼻症状 & & 0 & 0 \\
\hline
\end{tabular}

は16〜30年の間に襄胞が発見されることが多いように思 われた。

\section{6. 自覚症状}

本囊胞の症状は種々雑多であるが，そのほとんどが頼 部腫脹と頓部痛で, 一部が煩部不快感, 歯痛, 眼球突出 などといわれている。われわれの調査結果は表 5 のごと く, 頓部之口腔の両方に症状が垪存する症例が最も多く 


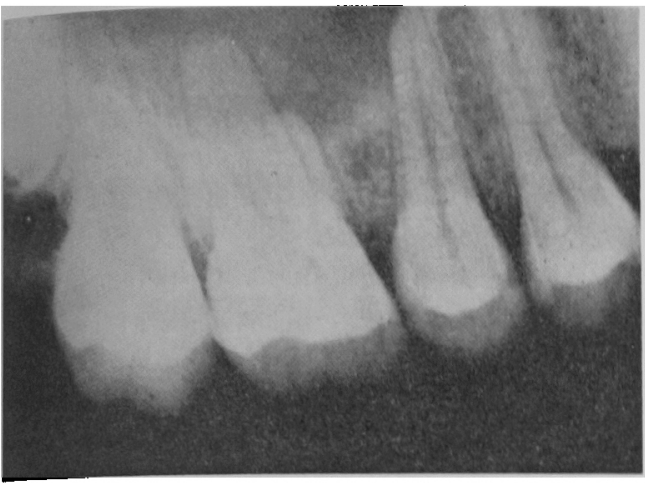

咅盷と橉根炎が接している症侧

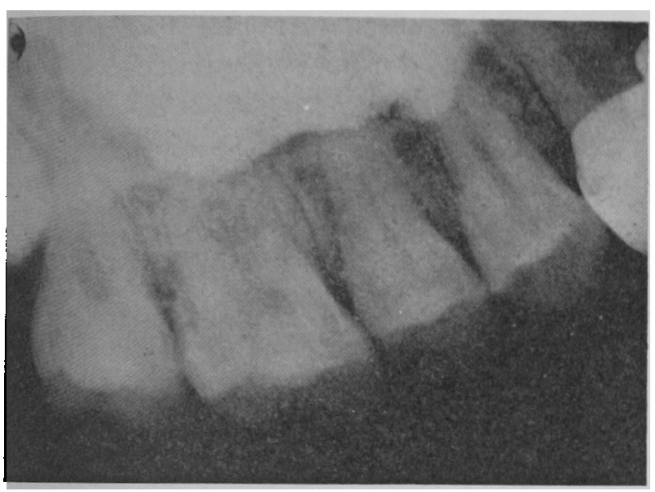

图 2 上図の造影郕による楾影像

(約72.4\%)，次が歯の疼痛ないしは異和感を主としてロ 䧑店状 (14.5\%) で，頓部应状のみは第 3 位の13.1\%で あり，眼症状および鼻症状のみの症例は 1 例もみられな 加た。

この㑯向は耳鼻咽喉科および眼科からの報告とは異な っており，歯科あるいは口腔外科を受診する患者の特徽 が現われるよらに思われた。

\section{7. 手術所見}

147例（152側）のすべてに Caldwell-Luc 法に準じた 手術法, すなわら単胞性のるのは対孔を作成し，多胞性 ののの隔壁を除去したのち対孔を作成した。 この手術 所見の調查から次のような結果が得られた。

a）栾胞の位置 : 手術所見で確認された剚胞の存在部 位を全体型, 上方型, 下方型に分類すると, 下方型が最 b多く95 例で， $62.5 \%$ を占めており，以下全体型 (47 例，30.9\%)，上方型 (10例，6.6\%）の順であった（表 6).

b) 潐胞の数 : 単胞性が86例 (56.6\%) で最む多く, 以下 2 胸性の38例 (25\%)，3 胞性の 24 例 (15.8\%)，4 胜の 4 例 (2.6\%) の順であった（表 6).

c) 自然孔および対孔の状態：ほとんどの症例が自然 孔，奶孔とるに骨性ないしは湾痕性閉鎖，あるいは著し

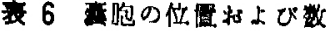

\begin{tabular}{|c|c|c|c|}
\hline \multicolumn{2}{|c|}{ 咆の们琏 } & K & \\
\hline 全体型 & 47 & 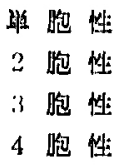 & $\begin{array}{r}22 \\
11 \\
10 \\
4\end{array}$ \\
\hline 上方型 & 10 & $\begin{array}{cc}\text { 単 胞 性 } \\
2 & \text { 胞 性 } \\
3 & \text { 胞 性 } \\
4 & \text { 胞 性 }\end{array}$ & $\begin{array}{l}3 \\
5 \\
2 \\
0\end{array}$ \\
\hline 下方型 & 95 & 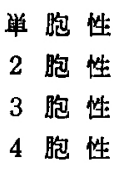 & $\begin{array}{r}61 \\
22 \\
12 \\
0\end{array}$ \\
\hline 尌 & 152 & & 152 \\
\hline
\end{tabular}

表 7 蹸の如嘈

\begin{tabular}{|c|c|}
\hline 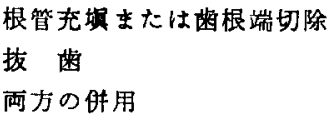 & $\begin{array}{r}39 \\
48 \\
4\end{array}$ \\
\hline 部 & 91 \\
\hline
\end{tabular}

表 8 整胞壁の種類

\begin{tabular}{c|r}
\hline 円柱上皮 & 65 \\
䋐毛上皮 & 19 \\
立方上皮 & 7 \\
扁平上皮 & 4 \\
\hline 計 & 95 \\
\hline
\end{tabular}

く狭窄の状態であった，多胞性の一部の症例には自然孔 および対孔の開存があったが，多胞性のため完全な交通 路としての用途は望めないるのであった。

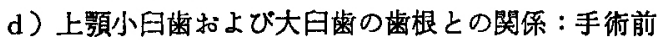
のX線像で国 2のよらな所見がみられたのは91例（約60 \%)であった. そのほとんどの症例は手術所見で根尖と 腊胞との間に骨の隔壁がなく，根尖部の上に咅胞壁ない しは瘢痕が存在していた。

これらの歯の処直の内容は表 7 のうで，39例には抜 䯠，根管充填および歯根端切除を行って歯を保存し，48 例には抜崡，4例には雨根端切除と抜崡が併用された。

\section{8. 胞の組䄳学的所見および内容液}

a) 組織学的所見：变胞壁，特に上皮の部分の組織な らびに電影的所見は手術所見とともに本衰胞の成り立ち を解明する重要な手がかりりなるために，多数の報告が 
ある

われわれは114 例について組䄉学的梌案を行らことが できたが，主要な所見である上皮がみられたのは95例 で，その結果は衰8のよ5で，円柱上皮か665例 (57\%) て最も多く，以下，線毛上皮 19 例 (16.7\%), 立方上皮7 例 $(6.1 \%)$ および直屏扁平上皮 4 例 (3.8\%) の内盹て あった.

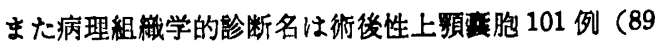
\%)で，他の13例 (11\%) は慢性副繁腔炎の合併であっ た.

b）内容液：㓥载のある130例についての调查結果は， 暗褐色から黑褐色の湌い粘液性あるいはコロイド状が54 例 $(42 \%)$ ，膿性か339例 $(30 \%)$ ，黃螕色の淡い粘液性か: 37例 $(28 \%)$ であった．しかし内容液の状想と英胞照と の関係は明らかでなかった。

\section{考案}

本研究で取り上げたそれぞれの調査結果を関係のある 文献統計と比較すると，各項目については大きな差異は みられなかった。 すなわち，男女の比はだいたい2：1 であり、これは副鼻腔炎手術を受ける患者は男性の汪う が約 2 倍多いことと関係があると思われる。

また，発生側については右側に多い,5,6)。 あるいは左

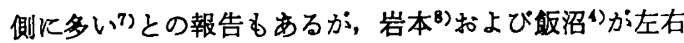
ほ注同数と報告しているように, 一般的には左右差はな いようであり，われわれの集計でも，左側66例，右側76 例で有意な左右差は認められなかった。

衰胞発見までの経過年数について10年から20年といら 報告が多く，われわれの集計でも同期間のものが最も多 数であった。 このことは本烡胞の発育がきわめて縟僈で あり, 洞壁部に発生してから外部に症状か出現するまで に成長するにはかなりの年月を経過していることを意味 するものであろ5. 田村 ${ }^{3)}$ は初回の副鼻腔炎手術は20歳 前後に, 飯沼“は11歳から20藏の間に最も多く行われて いると報告しているが，今回の調査でも，10歳から19歳 の間に手術が行われたものが全体の約 $63 \%$ を占めてい た。この手術年齢と本弯胞による何らかの症状が出現す るまでの期間を考虑すると，発見年龄は30〜 40歳が最 す 多いことになるが，実際の患者の年龄も30〜49歳の間か; 多く，約67\%を占めていた。

自覚症状は耳算咽陮科, 眼科および齿科の 3 科の領域 にわたっているが，歯科ないしは口腔外科受診の患者の 主訴をみると, 閉, 鼻漏, 嗅覚障害などの症状は少 なく, むしろ煩部の腫脹や疼痛, 上額菊肉頓移行部の腫 脹, 歯痛あるいは歯の異和感などの口腔症状が多いのが 特徽とされており，切開あるいは抜歯などによる磨形成 と排膿の症例も少なくない. その点は田村3)および飯沼4) らをはじめとする耳鼻咽喉科領域からの報告とはかなり
熼なってれり，われわれの洞查です，煩部・腔症状が $72.4 \%$ ，回胫淀状のみ $14.5 \%$ ，煩部症状のみ $13.1 \%$ の制 合で，限症状あるいは算症状のみのるのはなかった。 こ

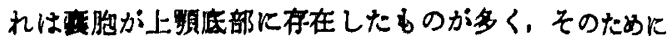

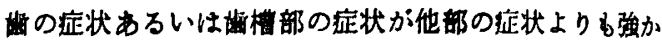
ったのであろらと思われる。

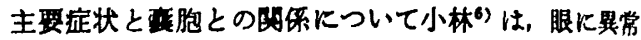
ををたしたるのを第】型，煩部に異常をさたしたるのを

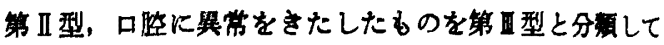
おり，岩本”は煩部症状型を第 I 型，眼症状型を第而，

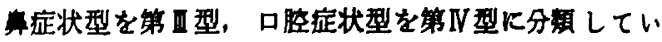

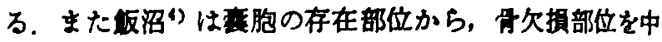
心に考えて，前型，前内型，前上型，前内上型下分頪し

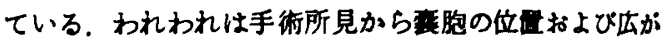
りを全体型，上方型および下方型に分類したが，下方型 が半数以上の $62.5 \%$ ，次いで全体型 $31 \%$ ，上方型 $6.5 \%$ の順であり，大多数が全体型との耳算吸喉科からの報告 とは異なる傾向であった。

本衰胞に上る症状出現には，気候的变化，感冒あるい は疲労などが馀因となっていることが多く，それは内容

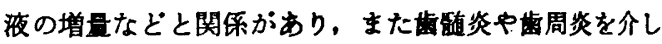
ての感染の波及とす関係があるといわれている。したが ってこのよらな急性炎症症状の場合には穿刺排腿法また は原因菌の抜去などによる娍王と，抗生物質の投与など で症状の消失する症例が少なくない，しかしこれらの治 療法は姑息的な対症療法であって最释的には手術が必要 である。

本䨢胞の手術にあたって特に注意すべき事項の1つ

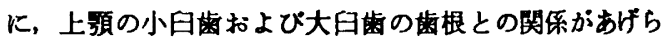
れている.この両者の関係について朝倉”は，雪と全く 関係ないむの，齿と関係あると思われるるの，および類 似疾患の 3 つに分類し，第 2 の場合にはあらかじあと の関係を十分に検討しておく必要があると述へでおり， また第 3 の代表的なものとして或性蓄胞があげられて (る, ${ }^{9,10)}$.

われわれの調查では，147 例中 87例にX線写真で歯根

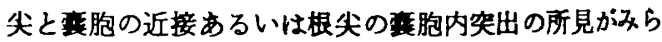
れた.このような症例については多種類のX線写真につ いて検討するととるに，歯髄診断器により歯面の生死を 確認したうえで，粘膜切開線の設定や齿の処膡を決定す る必要がある，小林 ${ }^{6}$ は婁胞底に露出している根尖と衰 胞壁との間に直接の関係はみられないと述べているが, 朝倉9) はその部分の歯槽骨には资症性変化が存在するこ とが多く，そのために，治意が妨げられて肉芽腫が形成 されると報告しており，また森本 ${ }^{11}$ 恃洞底部に残存した 粘膜に加えて，歯根肉芽腫からの 2 次的要素加㙋胞の発 生を助長するようであると述べている.

われわれが行った歯の処置の内容は表のよらであ る.すなわち、初回の洞炎手術の祭に歯の根尖が損侮さ 
れたか，あるいは萬胞が下方に增大して根尖が压迫され て噛死をきたしたのではないかと思われる齿，むるい はこの手街によって根尖が强侮される心配のある棈に対 しては齿根端切除を行って保存し，その上らな処是が不 可勒な齿は街前または手術時に技去して，感染源をな 〈ナことに努めている，術前のX線写真で，根尖が变胞 内突出しているよ5にみえる症例です，手術時に舅案 された所見は，齿根尖に烡胞辝が直接付着あるいは被原

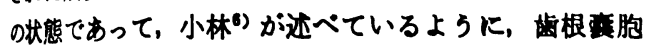
に淤るよらな歯根と烡胞等との咸保はみられなかっ た.

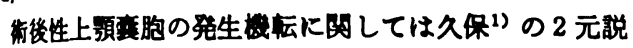

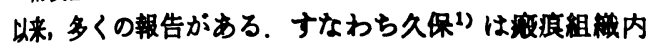
に埋没された洞粘莫からの分泌物が眝溜して生ずる眝滀

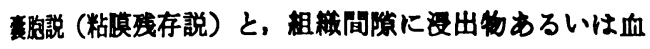

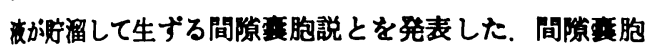
談化ついては現在ははとんど否定的であるが，眝溜蓄胞

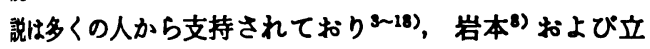

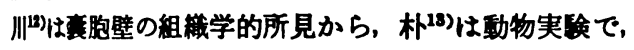
また田村》恃手術所見および組樴学的所見よりこれらを

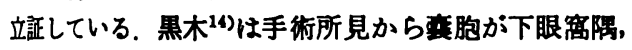
新骨突爬窩および歯槽突起窝に多く存在していたと報告 しており，われわれの手術所見でる索胞の存在部位は齿 情突起简部が最す多く，次いで煩骨突起窝が多くなって いた。 これらの窝部では洞炎手術の祭に粘膜の一部残存 线こりやすく，この残存粘膜が谼胞の発生源になりら ることは容易に推測されるところで症状の現れない潜在 生の䒾胞す存在するよらに思われる。.この点について小 獂(1)性洞炎手術後 1 年から52年を経過した179例，330 比ついてX線断首写真による検索を行い，76側に宾胞 を詔め，その約半数には症状が全くなかったと報告して いる. 赫 ${ }^{16}$ は再手術を行った22側中19側作立性の洞 を部め，その10側には内容液があったと報告している。

上預洞根治手術後の治窄は，上顆洞が液痕組織で充塞 されるか，あるいは対孔の部分からの上皮でおおかれて 㴔小洞となるのか理想とされているが，炎症の状的，術 慈感染の有無, 体質などによって経過が異なるようであ ろ.この点について赤池 ${ }^{16)}$ は再手術所見から莘胞の発生 下恃在粘莫は必ずしも必要ではなく, 忧後に上頻洞内 に曼入した粘膜で交通部が㵂断されることによっても蓄 俻か発生すると述へてており，土田常は何回かの上気道の 资应によって算腔との交通か狭くなり，强い狭窄ないし 注完全閉鎖か沈こると述べている。

战妱(18)は226例，毛利199は100例のそれぞれ臨床的観 蚆ら，待後の治思機転がある時期に障害され，病的粘 棋でおおかわた閉鎖腔が成立して萇胞が発生するのでは ないかと考えており，また村田 ${ }^{20}$ は粘膜残存が多い篩骨 同飞恃蕒胞が少なく，粘膜残存の比較的少ないはずの上 洞部にそれが多く発生するのは，悬腔との交通路の閉
鳀が原因であると述べている，われわれの 152 㑡では，

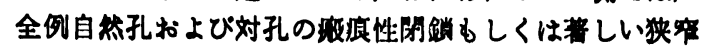
状热であり，しかもその多くの症例は単胞性湿胞であっ た. また手術後 2 年以队に再発した 3 例す戦胞性竞胞で あり，その内部は比校的平消な上皮でおおわれ，自然孔 および対孔からは完全に䀧性結合組維で䢞断されてい た.このよらな所見から洞炏手㧓後の経過のある時期に

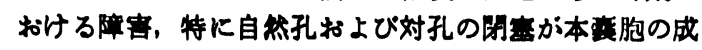
立と何らかの関係があることか推測されるのでかれわ れの手術法として，単胞性萑胞の合には大きな対孔の

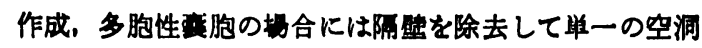
としてから対孔を作成する方法が通当であろらと考えら れた。

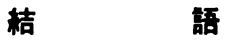

1972年 1 月から1977年 9 月までの 5 年 9 か月間に経嗆 した術後性上䫑蓄胞147例 (152側) について臨床的に検 討した結果は次のこととであった。

1. 性别，年龄別，患側别および X線所見は従来の報 告とほぼ同棣であった。

a）多発年龄は30〜 40荿で，経過年数は10〜20年が最 る多かった。

b）初回手術年㖮が若いものはど，経過年数が短い佰 向がみられた.

2. 主訴は耳算咽挣科からの報告と多少異なり, 頓部 十口腔症状の症例が多くみられた。

3. 歯と烡胞壁の関係は，根尖部に烡胞壁が付着ある いは被覆しているだけであり，齿根荎胞にみられるよう な関係ではなかった。

4. 手術法として, 単胞性のすのには対孔を作成し, 多胞性のものは隔壁を除去したのち対孔を作成する方法 が過当であると考えられた。

本論文の要旨の一部は第32回日本口腔科学会総会にお いて発表した。

\section{引用文 献}

1）久保猪之吉：上䫑洞根治手乪後に現われたる煩

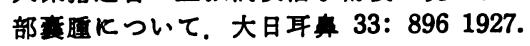

2) 堀内䄴一：京大星野教室における樶近 8 年間の

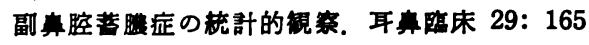
1934.

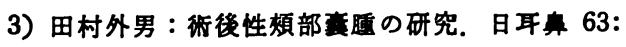
3191960.

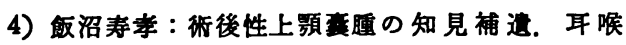
44: 5451972.

5) 中野 明：手征後性煩部蕰聥飞就て。大日耳 43: 4871937.

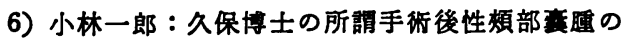




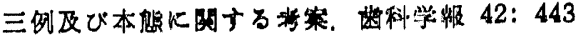
1937.

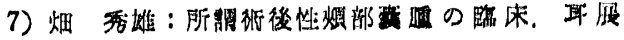
13: 6151970

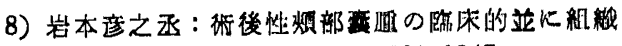

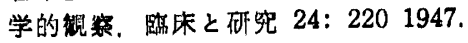

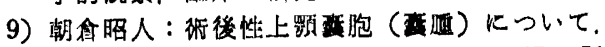
一口腔外科の立堨上り—耳限 47: 511 1975.

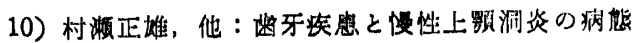

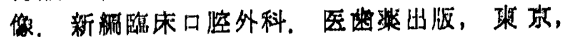
1968，216面.

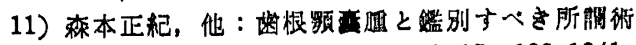

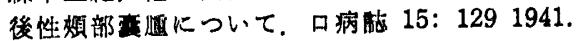

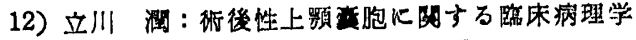
的研究。谏科学報 75: 11171975.

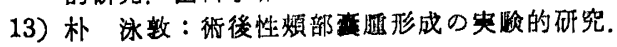

福附医誌 33(1)：1 1940 。

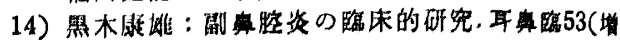
刊册 1): 11281960 .

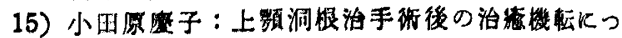
いての研究。耳度 8(綝 1):81 1965.

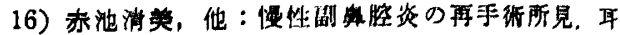
峥 39(9): 8211964.

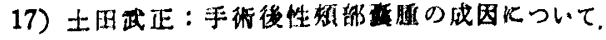
呯喉 44: 291972 .

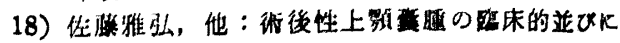

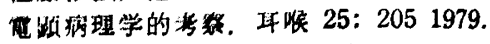

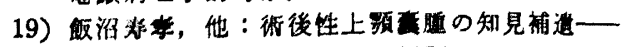

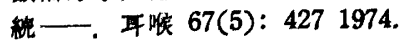

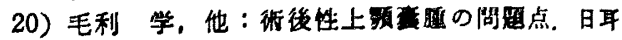
80: 3271977.

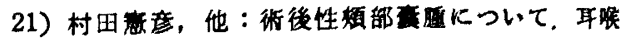
43(1): 371971 . 